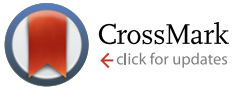

Cite this: Med. Chem. Commun., $2015,6,1186$

Received 28th April 2015, Accepted 12th May 2015

DOI: $10.1039 / c 5 m d 00185 d$

www.rsc.org/medchemcomm

\section{A novel aminotriazole-based NHC complex for the design of gold $(I)$ anti-cancer agents: synthesis and biological evaluation $\uparrow$}

\author{
T. V. Serebryanskaya, ${ }^{\text {*ac }}$ A. A. Zolotarev ${ }^{\mathrm{b}}$ and I. Ott ${ }^{\star a}$
}

\begin{abstract}
A novel gold(I) complex based on an aminotriazole $\mathrm{N}$-heterocylic carbene ligand represents a promising scaffold for the design of anticancer bioorganometallics. The complex triggered cytotoxic effects in HT-29 and MDA-MB-231 cancer cells, inhibited the activity of the enzyme thioredoxin reductase and showed an effective and fast cellular accumulation.
\end{abstract}

Besides their frequent and successful application in chemical catalysis, N-heterocyclic carbene (NHC) ligands represent a conveniently tunable and very fruitful platform for the design of new biologically active metal complexes and, in particular, highly potent gold(I)-based antiproliferative agents. ${ }^{1}$ The high biological activities of many gold NHC complexes have been established and their impact on cellular biochemistry and enzyme activities has been studied. ${ }^{2}$ Based on convenient access through standard synthetic methods, the majority of the biologically studied complexes contain NHC ligands obtained from imidazole or benzimidazole, while the biological properties of other types have been explored less intensively. Accordingly, this now triggers an increasing demand for the extension of the structural diversity of the coordinated NHC ligands. Recent examples where this issue has been addressed include bioactive 1,2,3-triazoles, ${ }^{3}$ heteroleptic pyrazoles, ${ }^{4}$ N/S-NHC complexes ${ }^{5}$ or several metal-NHC-(bio)conjugates. $^{2 i, 3,6}$ With the aim of extending the structure-activity relationships of the gold(I)-NHC pharmacophore, we present here the synthesis and biological evaluation of a novel aminotriazole-based NHC gold(I) complex, namely bis(1-tertbutyl-4-(tert-butylamino)-1,2,4-triazol-5-ylidene) gold(I) perchlorate (3 in Scheme 1).

The 1,2,4-triazolium perchlorate 1 was synthesized by excessive tert-butylation of 4-amino-1,2,4-triazole in acidic media according to a previously reported method. ${ }^{7}$ NHC

\footnotetext{
${ }^{a}$ Institute of Medicinal and Pharmaceutical Chemistry, Technische Universität Braunschweig, Beethovenstrasse 55, 38106 Braunschweig, Germany. E-mail: ingo.ott@tu-bs.de

${ }^{b}$ Institute of Earth Sciences, Saint Petersburg State University, University Emb. 7/9, 199034 Saint Petersburg, Russian Federation

${ }^{c}$ Institute of Chemistry, Saint Petersburg State University, Universitetsky Pr. 26, 198504 Stary Petergof, Russian Federation. E-mail: t.serebryanskaya@chem.spbu.ru $\dagger$ Electronic supplementary information (ESI) available: materials and methods, examples of NMR spectra, crystallographic results, Fig. S1-S5 and Tables S1-S3. See DOI: 10.1039/c5md00185d
}

complexes 2 and 3 were obtained using a modified silver(I) oxide procedure proposed by Wang and $\operatorname{Lin}^{8}$ (see Scheme 1).

According to the literature,,$^{1 f, 9}$ azolium salts containing weakly coordinating counterions such as $\mathrm{PF}_{6}{ }^{-}, \mathrm{BF}_{4}{ }^{-}$, or $\mathrm{ClO}_{4}{ }^{-}$ often do not react directly with $\mathrm{Ag}_{2} \mathrm{O}$ and the presence of an additional base such as $\mathrm{NaOH}$ is required. Some reports claim that a source of halide (for instance, trialkylammonium chloride) is also necessary for the reaction to proceed. ${ }^{1 f, 9}$ Due to this fact, a modification of the method by Wang and Lin has been recently proposed by Monkowius et al. allowing the smooth generation of $\mathrm{Ag}(\mathrm{NHC})_{2} \mathrm{Y}\left(\mathrm{Y}=\mathrm{PF}_{6}, \mathrm{SF}_{6}\right.$, or $\left.\mathrm{ClO}_{4}\right)$ from the corresponding imidazolium salt, using $\mathrm{AgCl}$ and an excess of $\mathrm{KOH}^{9 b}$ Referring to the established equilibrium between (NHC)AgX and $\left[\mathrm{Ag}(\mathrm{NHC})_{2}\right] \mathrm{AgX}_{2}$ in solution, the authors argued that $\mathrm{AgCl}$ was required as a source of chloride ion and postulated the formation of the ( $\mathrm{NHC}$ ) $\mathrm{AgCl}$ species as intermediates. Later, this procedure has been also applied for the synthesis of two homoleptic silver(I) carbene complexes derived from 1,2,4-triazolium perchlorate salts. ${ }^{10}$

Similar to the above mentioned results, we found that the triazolium salt 1 does not react with $\mathrm{Ag}_{2} \mathrm{O}$ in $\mathrm{CH}_{2} \mathrm{Cl}_{2}$ solution. However, the addition of other bases such as $\mathrm{K}_{2} \mathrm{CO}_{3}$ or $\mathrm{Na}_{2} \mathrm{CO}_{3}$ enabled the generation of the NHC complex. Particularly, treatment of 1 with $\mathrm{Ag}_{2} \mathrm{O}$ in the presence of 2 equiv. of $\mathrm{K}_{2} \mathrm{CO}_{3}$ in dry $\mathrm{CH}_{2} \mathrm{Cl}_{2}$ resulted in the formation of 2 with a good

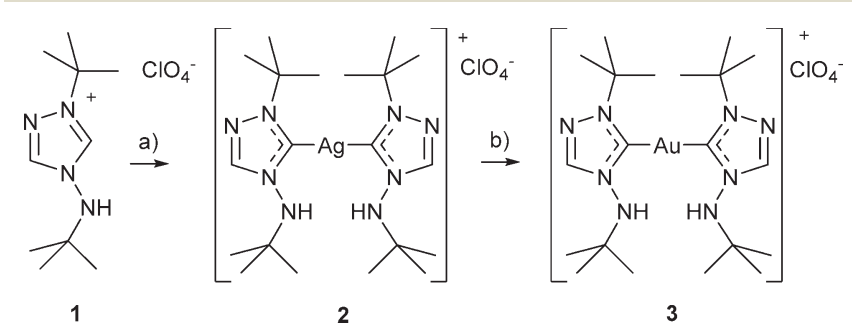

Scheme 1 Synthesis of triazole-based silver(I) and gold(I) NHC complexes; a) $\mathrm{Ag}_{2} \mathrm{O}, \mathrm{K}_{2} \mathrm{CO}_{3}$; b) $\left(\mathrm{CH}_{3}\right)_{2} \mathrm{SAuCl}$. 
yield (88\%). Complex 2 was isolated and characterized by elemental analysis, IR and NMR $\left({ }^{1} \mathrm{H}\right.$ and $\left.{ }^{13} \mathrm{C}\right)$ spectroscopy. The preparation of single crystals of 2 was impossible due to its sensitivity to light. For this reason, 2 was kept in the dark and utilized for the synthesis of the gold(I) complex in a timely manner. Gold(I) NHC complex 3 was obtained from 2 using the standard transmetallation procedure $^{1 g}$ and $\left(\mathrm{CH}_{3}\right)_{2} \mathrm{SAuCl}$ was the source of gold. Its composition and structure was confirmed by elemental analysis, HRESI mass spectrometry, IR and NMR $\left({ }^{1} \mathrm{H}\right.$ and $\left.{ }^{13} \mathrm{C}\right)$ spectroscopy, and single crystal X-ray analysis. $\S$ The results of the elemental analyses and HRESI MS are in good agreement with the proposed structures. The $\mathrm{ESI}^{(+)}$mass spectrum of 3 exhibits one intensive peak corresponding to the $\left[\mathrm{Au}(\mathrm{NHC})_{2}\right]^{+}$ion. Coordination of the NHC ligand was confirmed by the ${ }^{1} \mathrm{H}$ and ${ }^{13} \mathrm{C}$ NMR spectra of the complexes (see Fig. S1-S4 in the ESI $\dagger$ ). Particularly, the ${ }^{1} \mathrm{H}$ NMR spectra of 2 and 3 lack the signal of the $\mathrm{C}(5) \mathrm{H}$ proton that is observed at $9.74 \mathrm{ppm}$ in the spectrum of the triazolium salt $1^{7}$ The formation of the metalcarbon bond also leads to a significant (up to $38 \mathrm{ppm}$ ) downfield shift of $\mathrm{C}(5)$ resonances in comparison with the spectrum of the precursor salt (145.3 $\mathrm{ppm})$. The ${ }^{13} \mathrm{C}$ NMR spectrum of 3 displays a singlet resonance at $183.2 \mathrm{ppm}$, whereas in the spectrum of silver(I) complex 2 the carbene carbon appears as a doublet of doublets due to fully resolved coupling to both silver isotopes $\left[{ }^{1} J\left({ }^{13} \mathrm{C}-{ }^{107} \mathrm{Ag}\right)=190.3 \mathrm{~Hz}\right.$; $\left.{ }^{1} J\left({ }^{13} \mathrm{C}-{ }^{109} \mathrm{Ag}\right)=219.5 \mathrm{~Hz}\right]$, which can be quite rarely observed experimentally. ${ }^{1 f, 9 a}$ Besides, the $\mathrm{C}(3)$ triazole endocyclic carbon also appears as a doublet due to ${ }^{3} J\left(\mathrm{C}-{ }^{107 / 109} \mathrm{Ag}\right)$ coupling

\$ Synthesis of bis(1-tert-butyl-4-(tert-butylamino)-1,2,4-triazol-5-ylidene)silver(I) perchlorate (2); $0.50 \mathrm{mmol}(116 \mathrm{mg})$ of $\mathrm{Ag}_{2} \mathrm{O}, 1.0 \mathrm{mmol}(296 \mathrm{mg})$ of 1 and 2 mmol $(138 \mathrm{mg})$ of anhydrous $\mathrm{K}_{2} \mathrm{CO}_{3}$ were suspended in $20 \mathrm{~mL}$ of dry $\mathrm{CH}_{2} \mathrm{Cl}_{2}$. The suspension was stirred under nitrogen atmosphere at RT for $48 \mathrm{~h}$. Then unreacted $\mathrm{Ag}_{2} \mathrm{O}$ was filtered off, and the filtrate was evaporated to dryness. The off-white crystalline residue of 2 was kept in the dark. Yield: $266 \mathrm{mg}$ (88\%). Anal. Calc. for $\mathrm{C}_{20} \mathrm{H}_{40} \mathrm{AgClN}_{8} \mathrm{O}_{4}$ : C, 40.04; H, 6.72; N, 18.68. Found: C, 40.28; H, 6.91; $\mathrm{N}, 18.63 \% .{ }^{1} \mathrm{H}$ NMR [400 MHz, $\left.\mathrm{CDCl}_{3}, \delta(\mathrm{ppm})\right]: 8.32(\mathrm{~s}, 1 \mathrm{H}, \mathrm{C}(3) \mathrm{H}) ; 5.99(\mathrm{~s}, 1 \mathrm{H}$, $\mathrm{NH}) ; 1.75$ (s, 9H, $\left.{ }^{t} \mathrm{Bu}\right) ; 1.22\left(\mathrm{~s}, 9 \mathrm{H},{ }^{t} \mathrm{Bu}\right) .{ }^{13} \mathrm{C}$ NMR $\left[100 \mathrm{MHz}, \mathrm{CDCl}_{3}, \delta(\mathrm{ppm}), J\right.$ $(\mathrm{Hz})]: 179.5\left(\mathrm{dd},{ }^{1} \mathrm{~J}\left(\mathrm{C},{ }^{109} \mathrm{Ag}\right)=219.5,{ }^{1} J\left(\mathrm{C},{ }^{107} \mathrm{Ag}\right)=190.3, \mathrm{C}(5)\right) ; 143.1\left(\mathrm{~d},{ }^{3} J(\mathrm{C}, \mathrm{Ag})\right.$ $=5.9, \mathrm{C}(3)) ; 61.4\left(\mathrm{~s}, \mathrm{C}\left(\mathrm{CH}_{3}\right)_{3}\right) ; 55.7\left(\mathrm{~s}, \mathrm{C}\left(\mathrm{CH}_{3}\right)_{3}\right) ; 30.9\left(\mathrm{~s}, \mathrm{CH}_{3}\right.$ from $\left.{ }^{t} \mathrm{Bu}\right) ; 28.1(\mathrm{~s}$, $\mathrm{CH}_{3}$ from ${ }^{t} \mathrm{Bu}$ ). FT-IR $\left(v, \mathrm{~cm}^{-1}\right)$ : 3287 (vs), 3156 (m), 3135 (m), 3095 (w), 2968 (vs), 2932 (s), 2906 (s), 2872 (s), 1550 (m), 1467 (s), 1412 (s), 1395 (s), 1366 (s), $1303(\mathrm{~m}), 1259$ (w), 1229 (m), 1205 (s), 1113 (sh), 1067 (vs br), 971 (m), 932 (w), $874(\mathrm{~s}), 821(\mathrm{w}), 772(\mathrm{w}), 713(\mathrm{~s}), 648(\mathrm{~s}), 622(\mathrm{vs}), 592(\mathrm{~s}), 543(\mathrm{w}), 463(\mathrm{~m})$.

$\S$ Synthesis of bis(1-tert-butyl-4-(tert-butylamino)-1,2,4-triazol-5-ylidene)gold(I) perchlorate (3); $0.41 \mathrm{mmol}(247 \mathrm{mg})$ of 2 and $0.40 \mathrm{mmol}(118 \mathrm{mg})$ of $\left(\mathrm{SMe}_{2}\right) \mathrm{AuCl}$ were dissolved in $20 \mathrm{~mL}$ of dry $\mathrm{CH}_{2} \mathrm{Cl}_{2}$. The solution was stirred under nitrogen atmosphere at RT for $24 \mathrm{~h}$. Then the reaction mixture was filtered, and the filtrate was evaporated to dryness to give colorless crystalline product 3 . Single crystals of 3 were obtained from $\mathrm{CH}_{2} \mathrm{Cl}_{2} /$ hexane $(1: 1, \mathrm{v} / \mathrm{v})$. Yield: $252 \mathrm{mg}(91 \%)$. Anal. Calc. for $\mathrm{C}_{20} \mathrm{H}_{40} \mathrm{AuClN}_{8} \mathrm{O}_{4}$ : C, 34.84; $\mathrm{H}, 5.85 ; \mathrm{N}, 16.26$. Found: $\mathrm{C}, 35.04 ; \mathrm{H}$, 5.72; N, 16.19\%. HRMS $\left(\mathrm{ESI}^{+}, 100 \mathrm{~V}, \mathrm{CH}_{2} \mathrm{Cl}_{2}, \mathrm{~m} / \mathrm{z}\right): 589.3040\left[\mathrm{Au}(\mathrm{NHC})_{2}\right]^{+}$, (calcd. 589.3041). DSC/TG: $228-229{ }^{\circ} \mathrm{C}(\mathrm{mp}) ; 257{ }^{\circ} \mathrm{C}\left(T_{\max }\right.$, endothermal dec.). ${ }^{1} \mathrm{H}$ NMR $\left[400 \mathrm{MHz}, \mathrm{CDCl}_{3}, \delta(\mathrm{ppm})\right]: 8.38(\mathrm{~s}, 1 \mathrm{H}, \mathrm{C}(3) \mathrm{H}) ; 5.95(\mathrm{~s}, 1 \mathrm{H}, \mathrm{NH}) ; 1.84(\mathrm{~s}, 9 \mathrm{H}$, $\left.{ }^{t} \mathrm{Bu}\right) ; 1.24\left(\mathrm{~s}, 9 \mathrm{H},{ }^{t} \mathrm{Bu}\right) .{ }^{13} \mathrm{C}$ NMR [100 MHz, $\left.\mathrm{CDCl}_{3}, \delta(\mathrm{ppm}), J(\mathrm{~Hz})\right]: 183.2(\mathrm{~s}, \mathrm{C}(5))$; $142.9(\mathrm{~s}, \mathrm{C}(3)) ; 62.8\left(\mathrm{~s}, \mathrm{C}\left(\mathrm{CH}_{3}\right)_{3}\right) ; 56.2\left(\mathrm{~s}, \mathrm{C}\left(\mathrm{CH}_{3}\right)_{3}\right) ; 31.2\left(\mathrm{~s}, \mathrm{CH}_{3}\right.$ from $\left.{ }^{t} \mathrm{Bu}\right) ; 28.1(\mathrm{~s}$, $\mathrm{CH}_{3}$ from $\left.{ }^{t} \mathrm{Bu}\right)$. FT-IR $\left(v, \mathrm{~cm}^{-1}\right): 3287(\mathrm{~s}), 3138(\mathrm{~m}), 3103(\mathrm{w}), 2969(\mathrm{~s}), 2935(\mathrm{~m})$, 2907 (m), $2874(\mathrm{~m}), 1553(\mathrm{~m}), 1470(\mathrm{~s}), 1413(\mathrm{~s}), 1397(\mathrm{~s}), 1367(\mathrm{~s}), 1307$ (m), $1261(\mathrm{w}), 1230(\mathrm{~m}), 1203$ (s), 1116 (sh), 1067 (vs br), 978 (m), 934 (w), 872 (s), $821(\mathrm{~m}), 773(\mathrm{w}), 713(\mathrm{~m}), 653(\mathrm{~s}), 620(\mathrm{vs}), 592(\mathrm{~s}), 547(\mathrm{w}), 465(\mathrm{~m})$.
$(5.9 \mathrm{~Hz})$. The observed chemical shifts and ${ }^{1} J\left(\mathrm{C}-{ }^{107 / 109} \mathrm{Ag}\right)$ coupling constants fall in the range previously described for $\left[\mathrm{Ag}(\mathrm{NHC})_{2}\right]^{+}$complexes. $^{1 f, 9 a, 10,11}$

Complexes 2 and 3 exhibit almost identical mid-IR spectra indicating their similar structures. For instance, the spectra of both complexes display intensive broad bands at $\mathrm{ca} .1100$ and $620 \mathrm{~cm}^{-1}$ assigned to $v_{\text {as }}\left(\mathrm{ClO}_{4}\right)$ stretching and $\delta\left(\mathrm{ClO}_{4}\right)$ deformation vibrations, respectively, of the uncoordinated perchlorate ion. ${ }^{12}$ Thermal stability of 3 was additionally studied by TG/DSC analysis. The complex was found to be stable up to $220-230{ }^{\circ} \mathrm{C}$, its melting at $228-229{ }^{\circ} \mathrm{C}$ being followed by a two-step endothermal decomposition at 250$270{ }^{\circ} \mathrm{C}$. The molecular and crystal structure of 3 was additionally confirmed by single crystal X-ray study, however only with low resolution (see Fig. S5 and Tables S1-S3†).

Many gold(I)-based NHC complexes, both neutral and cationic, are known as effective tumor cell growth inhibitory and pro-apoptotic agents that are able to trigger cell death via inhibition of the enzyme thioredoxin reductase (TrxR), induce reactive oxygen species formation, and cause antimitochondrial activities and other antitumoral effects. ${ }^{1 a, 2 a-d, g, h, k}$ In order to evaluate the key biological properties of the aminotriazole NHC complex 3, we determined its antiproliferative effects in two selected cancer cell lines (namely, HT-29 colon carcinoma and MDA-MB-231 breast adenocarcinoma) and its effectivity as an inhibitor of TrxR.

Complex 3 demonstrated good cytotoxic effects in both cell lines with $\mathrm{IC}_{50}$ values in the low micromolar range $(2.1 \pm$ $0.0 \mu \mathrm{M}$ in the HT-29 and $1.0 \pm 0.0 \mu \mathrm{M}$ in the MDA-MB-231 cells). This is in good agreement with previous studies using imidazole and benzimidazole-based cationic $\left[\mathrm{Au}(\mathrm{NHC})_{2}\right]^{+}$ complexes in the same assay, which afforded $\mathrm{IC}_{50}$ values in a comparable range. ${ }^{13}$ The precursor triazolium perchlorate 1 was used as a negative control and, as expected, showed no antiproliferative activity in concentrations up to $100 \mu \mathrm{M}$. Complex 3 also showed moderate TrxR inhibition activity with an $\mathrm{IC}_{50}$ value of $1.2 \pm 0.6 \mu \mathrm{M}$ as measured in the DTNB reduction assay, again comparable with the other [Au$\left.(\mathrm{NHC})_{2}\right]^{+}$complexes. ${ }^{13}$ Importantly, TrxR is considered to be one of the most important biological targets of $\mathrm{Au}^{\mathrm{I}}$-based drugs. $^{2 a, c, d, 13 a, 14}$

Cellular gold uptake was assessed using high resolution continuum source atomic absorption spectroscopy (HR CS AAS) and measured in the HT-29 cells exposed to $2.0 \mu \mathrm{M}$ (approx. $\mathrm{IC}_{50}$ value) or $10 \mu \mathrm{M}$ of 3 for a period of 1,4 or $8 \mathrm{~h}$. The results of the experiment are given in Fig. 1 as nanomole of Au per milligram of protein. The respective values of intracellular molar gold concentrations were obtained based on certain biophysical parameters of the HT-29 cells. $^{15}$ According to the results, complex 3 led to very high cellular gold levels of up to $450 \mu \mathrm{M}$ upon incubation with $10 \mu \mathrm{M}$, corresponding to an approximately 45 -fold cellular accumulation with respect to the extracellular medium. Since levels after 1 and 4 hours were comparable, it can be concluded that the complex was quickly taken up by the cells. This was followed by decreased cellular gold levels after $8 \mathrm{~h}$, and this effect was 


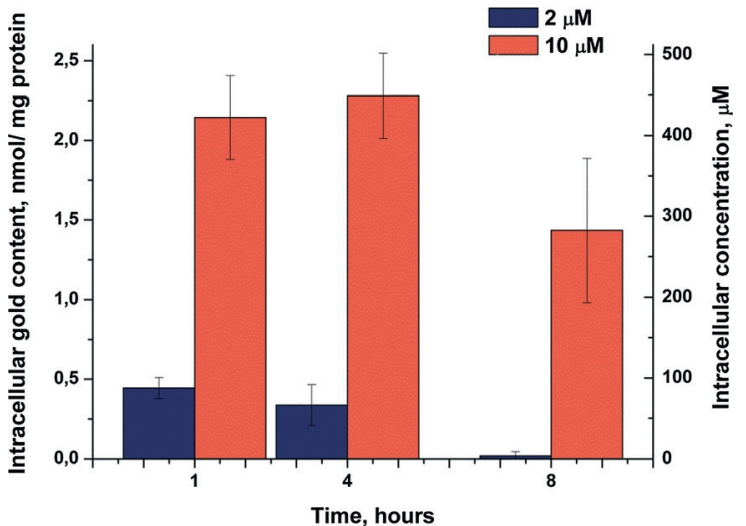

Fig. 1 Cellular gold content of HT-29 cells exposed to $2.0 \mu \mathrm{M}$ or 10 $\mu \mathrm{M}$ of gold(I) complex 3 .

in particular highly pronounced with the concentration close to the $\mathrm{IC}_{50}$ value of cytotoxicity $(2.0 \mu \mathrm{M})$. In general, the values are within the same order of magnitude as observed recently with a cationic biscarbene NHC complex, which had reached cellular gold levels (in the MCF-7 breast adenocarcinoma cells) in the range of 1.0-1.5 nmol mg $\mathrm{mb}^{-1}$ at an exposure concentration of $3.0 \mu \mathrm{M} .^{13 a}$ However, in these previous experiments, stable gold levels were observed.

\section{Conclusions}

Complex 3 was synthesized via the silver(I) oxide route and was fully characterized using spectroscopic and structural methods. According to the results of the biological evaluation, it showed marked antiproliferative activity against HT-29 and MDA-MB-231 tumor cell lines with IC $_{50}$ values in the low micromolar range $(1-2 \mu \mathrm{M})$ and good to moderate activity as inhibitor of TrxR. Cellular uptake studies showed a fast and efficient accumulation in HT-29 cells that was followed by decreased gold concentrations after $8 \mathrm{~h}$. This pattern could be attributed to the fast uptake related to the cationic charge and lipophilic nature of 3 and a subsequent excretion of gold, which might be the consequence of active transport processes or metabolism. Of note, the enhanced excretion of gold is less evident at higher concentration above the $\mathrm{IC}_{50}$ value of cytotoxicity $(10 \mu \mathrm{M})$ when cell homeostasis is strongly affected by the toxic effects.

The aminotriazole moiety of 3 is of particular interest since it displays certain possible advantages for metallodrug development. First, with its $\mathrm{N}$-amino group it represents a comparably hydrophilic NHC core that could be used in the design of novel bioactive gold bioorganometallics and might overcome common solubility issues. Secondly, it could also be speculated that this NH group next to the NHC might facilitate additional interactions with the molecular targets of the complex. And thirdly, in comparison with the much more frequently studied imidazole-based carbenes, NHC ligands based on other heterocycles, particularly 1,2,4-triazole derivatives, may show altered electronic properties and donor ability. ${ }^{16}$

Concerning the structure-activity relationships, the following conclusions can be drawn: 1) the expected impact of the gold center was clearly established as 3 was active against tumor cell growth in contrast to the metal free 1, and 2) the mode of drug action of 3 is likely dominated by the combination of the gold-based inhibition of TrxR and the antimitochondrial effects related to the cationic nature of the compound, as it has also been observed with other complexes of this general type. ${ }^{1 a, 2 b, g, 13 a}$

\section{Acknowledgements}

The postdoctoral fellowships for T. V. S. by the DAAD (Deutscher Akademischer Austauschdienst) and Saint Petersburg State University (grant 12.50.1560.2013) is gratefully acknowledged. The HRESI MS and X-ray diffraction studies were performed at the Center for Chemical Analysis and Materials Research and at the Research Center for X-ray Diffraction Studies of St. Petersburg State University.

\section{Notes and references}

1 (a) L. Oehninger, R. Rubbiani and I. Ott, Dalton Trans., 2013, 42, 3269; (b) F. Cisnetti and A. Gautier, Angew. Chem., Int. Ed., 2013, 52, 11976; (c) A. Gautier and F. Cisnetti, Metallomics, 2012, 4, 23; (d) W. Liu and R. Gust, Chem. Soc. Rev., 2013, 42, 755; (e) L. Mercs and M. Albrecht, Chem. Soc. Rev., 2010, 39, 1903; $(f)$ J. C. Lin, R. T. Huang, C. S. Lee, A. Bhattacharyya, W. S. Hwang and I. J. Lin, Chem. Rev., 2009, 109, 3561; $(g)$ K. M. Hindi, M. J. Panzner, C. A. Tessier, C. L. Cannon and W. J. Youngs, Chem. Rev., 2009, 109, 3859; (h) M. N. Hopkinson, C. Richter, M. Schedler and F. Glorius, Nature, 2014, 510, 485.

2 (a) A. Pratesi, C. Gabbiani, E. Michelucci, M. Ginanneschi, A. M. Papini, R. Rubbiani, I. Ott and L. Messori, J. Inorg. Biochem., 2014, 136, 161; (b) X. Cheng, P. Holenya, S. Can, H. Alborzinia, R. Rubbiani, I. Ott and S. Wölfl, Mol. Cancer, 2014, 13, 221; (c) P. Holenya, S. Can, R. Rubbiani, H. Alborzinia, A. Jünger, X. Cheng, I. Ott and S. Wölfl, Metallomics, 2014, 6, 1591; (d) R. Rubbiani, L. Salassa, A. de Almeida, A. Casini and I. Ott, ChemMedChem, 2014, 9, 1205; (e) T. Zou, C. T. Lum, C.-N. Lok, W.-P. To, K.-H. Low and C.-M. Che, Angew. Chem., Int. Ed., 2014, 53, 5810; $(f)$ T. Zou, C. T. Lum, S. S.-Y. Chui and C.-M. Che, Angew. Chem., Int. Ed., 2013, 52, 1; $(g)$ J. L. Hickey, R. A. Ruhayel, P. J. Barnard, M. V. Baker, S. J. Berners-Price and A. Filipovska, J. Am. Chem. Soc., 2008, 130, 12570; (h) E. Schuh, C. Pflüger, A. Citta, A. Folda, M. P. Rigobello, A. Bindoli, A. Casini and F. Mohr, J. Med. Chem., 2012, 55, 5518; (i) B. Bertrand, L. Stefan, M. Pirrotta, D. Monchaud, E. Bodio, P. Richard, P. Le Gendre, E. Warmerdam, M. H. de Jager, G. M. Groothuis, M. Picquet and A. Casini, Inorg. Chem., 2014, 53, 2296; $(j) \mathrm{L}$. Boselli, I. Ader, M. Carraz, C. Hemmert, O. Cuvillier and H. Gornitzka, Eur. J. Med. Chem., 2014, 85, 87; (k) A. Nandy, 
S. K. Dey, S. Das, R. N. Munda, J. Dinda and K. D. Saha, Mol. Cancer, 2014, 13, 57; (l) M. Baron, S. Bellemin-Laponnaz, C. Tubaro, M. Basato, S. Bogialli and A. Dolmella, J. Inorg. Biochem., 2014, 141, 94.

3 S. D. Köster, H. Alborzinia, S. Can, I. Kitanovic, S. Wölfl, R. Rubbiani, I. Ott, P. Riesterer, A. Prokop, K. Merz and N. Metzler-Nolte, Chem. Sci., 2011, 3, 2062.

4 (a) H. Sivaram, J. Tan and H. V. Huynh, Dalton Trans., 2013, 42, 12421; (b) H. Sivaram, J. Tan and H. V. Huynh, Organometallics, 2012, 31, 5875.

5 A. Gutiérrez, M. C. Gimeno, I. Marzo and N. Metzler-Nolte, Eur. J. Inorg. Chem., 2014, 2512.

6 (a) A. Meyer, L. Oehninger, Y. Geldmacher, H. Alborzinia, S. Wolfl, W. S. Sheldrick and I. Ott, ChemMedChem, 2014, 9, 1794; (b) J. K. Muenzner, B. Biersack, H. Kalie, I. C. Andronache, L. Kaps, D. Schuppan, F. Sasse and R. Schobert, ChemMedChem, 2014, 9, 1195.

7 S. V. Voitekhovich, A. S. Lyakhov, L. S. Ivashkevich, V. E. Matulis, Y. V. Grigoriev, P. N. Gaponik and O. A. Ivashkevich, Tetrahedron, 2012, 68, 4962.

8 H. M. J. Wang and I. J. B. Lin, Organometallics, 1998, 17, 972.

9 (a) J. C. Garrison and W. J. Youngs, Chem. Rev., 2005, 105, 3978; (b) M. Kriechbaum, J. Hölbling, H.-G. Stammler, M. List, R. J. F. Berger and U. Monkowius, Organometallics, 2013, 32, 2876.
10 J. Turek, Z. Růžičková and A. Růžička, Inorg. Chem. Commun., 2014, 48, 103.

11 J. Turek, I. Panov, P. Svec, Z. Ruzickova and A. Ruzicka, Dalton Trans., 2014, 43, 15465.

12 K. Nakamoto, Infrared and Raman Spectra of Inorganic and Coordination Compounds. Part B: Applications in Coordination, Organometallic and Bioinorganic Chemistry, John Wiley \& Sons, Inc, Hoboken, New Jersey, 2009.

13 (a) R. Rubbiani, S. Can, I. Kitanovic, H. Alborzinia, M. Stefanopoulou, M. Kokoschka, S. Monchgesang, W. S. Sheldrick, S. Wolfl and I. Ott, J. Med. Chem., 2011, 54, 8646; (b) R. Rubbiani, E. Schuh, A. Meyer, J. Lemke, J. Wimberg, N. Metzler-Nolte, F. Meyer, F. Mohr and I. Ott, Med. Chem. Commun., 2013, 4, 942.

14 (a) A. Bindoli, M. P. Rigobello, G. Scutari, C. Gabbiani, A. Casini and L. Messori, Coord. Chem. Rev., 2009, 253, 1692; (b) A. Casini, C. Gabbiani, F. Sorrentino, M. P. Rigobello, A. Bindoli, T. J. Geldbach, A. Marrone, N. Re, C. G. Hartinger, P. J. Dyson and L. Messori, J. Med. Chem., 2008, 51, 6773; (c) S. Gromer, L. D. Arscott, C. H. Williams, R. H. Schirmer and K. Becker, J. Biol. Chem., 1998, 273, 20096.

15 I. Ott, H. Scheffler and R. Gust, ChemMedChem, 2007, 2, 702.

16 (a) D. J. Nelson and S. P. Nolan, Chem. Soc. Rev., 2013, 42, 6723; (b) T. Droege and F. Glorius, Angew. Chem., Int. Ed., 2010, 49, 6940. 